\title{
SEED WATER UPTAKE RELATES GERMINATION AND EMERGENCE POTENTIAL OF WHITE COATED FRENCH BEAN CULTIVARS
}

\author{
Sıtkı ERMIŞ ${ }^{*}$, Güleda ÖKTEM${ }^{1}$, İbrahim DEMIR ${ }^{2}$ \\ ${ }^{1}$ Variety Registration and Seed Certification Center, 06172, Ankara, Turkey \\ ${ }^{2}$ Ankara University, Faculty of Agriculture, Department of Horticulture, 06110, Ankara, Turkey
}

\begin{abstract}
Water uptake was related to germination (\%), seedling emergence (\%), mean germination time (h), and electrical conductivity $\left(\mu \mathrm{Scm}^{-1} \mathrm{~g}^{-1}\right)$ of nine French bean seed cultivars. Normal germination percentages were ranged between 43 and $99 \%$, seedling emergence 45 and $88 \%$, RE was between 43 and $100 \%$, electrical conductivity 48.5 and $144.1\left(\mu \mathrm{Scm}^{-1} \mathrm{~g}^{-1}\right)$, mean germination time $\left(0.95\right.$ and $1.82 \mathrm{~d}$ ). Seed water uptake at $25^{\circ} \mathrm{C}$ varied 20.43 and $50.89 \%$ after $2 \mathrm{~h}$ and 32.47 and $56.36 \%$ after 6 h. Seed water uptake (\%) after 2 and $6 \mathrm{~h}$ imbibition was significantly correlated with normal germination percentages $\left(\mathrm{R}^{2}=0.82, \mathrm{P}<0.01,0.77, \mathrm{P}<\right.$ $0.05)$, normal seedling emergence $\left(R^{2}=0.76, P<0.05, R^{2}=0.93, P<0.001\right)$, mean germination time $\left(R^{2}=0.77, P<0.05, R^{2}=0.66, P<0.05\right)$, and electrical conductivity $\left(\mathrm{R}^{2}=0.73, \mathrm{P}<0.05, \mathrm{R}^{2}=0.83, \mathrm{P}<0.01\right)$. Results were interpreted by prediction of water uptake in relation to seed germination and emergence.
\end{abstract}

Keywords: Beans, Seed quality, Imbibition, Seedling emergence, Mean germination time

\begin{tabular}{|c|c|c|}
\hline \multicolumn{3}{|c|}{$\begin{array}{l}\text { *Corresponding author: Variety Registration and Seed Certification Center, 06172, Ankara, Turkey } \\
\text { E mail: seedman37@gmail.com (S. ERMIȘ) }\end{array}$} \\
\hline Sıtkı ERMIŞ & https://orcid.org/0000-0003-4919-921X & Received: January 18, 2022 \\
\hline Güleda ÖKTEM & https://orcid.org/0000-0002-1749-4903 & Accepted: February 18, 2022 \\
\hline İbrahim DEMIR & https://orcid.org/0000-0003-4515-0689 & Published: April 01, 2022 \\
\hline
\end{tabular}

\section{Introduction}

Germination is a triphasic physiological process (Nonogaki et al., 2010). In the first phase, fast imbibition (increase in seed weight), a stable period in the second and fast imbibition end up with radicle emergence in the third. This extent of this process is related to various seed characteristics such as seed coat colour (Abdullah et al., 1991, Legesse and Powell, 1992, Zhang et al., 2006), seed ageing (Balesevic-Tubic et al., 2005, Zhang et al., 2006), seed maturation (Legesse and Powell, 1992, Shephard and Naylor, 1996), imbibition temperature and seed coat damage (Powell et al., 1986). In legumes, imbibition is a very influential stage of seed quality, in these species, fast imbibition damages cell structures and causes high solute leakage (i.e electrical conductivity). Solute leakage causes fungi infection around the seed, seedbed and seed death occurs. This is the basic reason why electrical conductivity is used as a seed vigour test in legume species (Matthews and Powell, 2011). Death due to the fast water uptake is also named, imbibitional chilling injury when sown at low temperature $\left(10^{\circ} \mathrm{C} \geq\right)$, low seed moisture content (i.e., 10\% $\geq$ ) and seed coat damages (cracks on the surface) accelerate the amount of solute leakage and reduce stand establishment in the field i.e., peas, beans, soybeans (Powell et al., 1986, Demir, 1996). Sowing was done in wet and cold soil conditions in northern Europe. However, unlike northern, the Mediterranean region, legumes are not necessarily sown in cold and wet soils. Legumes in such areas are commonly sown as a second crop following wheat and barley harvest where the soil temperature is reasonably high and soil is not wet at all i.e., end of June. So, when seed moisture is raised to i.e., $13 \% \leq$ and soil temperatures are high then imbibitional injury is less likely to occur (Demir, 1996) since seed does not take water very fast. Moreover, the temperature may not accelerate the negative effect. Normally, a temperature of $>30^{\circ} \mathrm{C}$ during the day or $>20^{\circ} \mathrm{C}$ at night causes seeds to germinate. Therefore, planting beans in the field should be limited to temperate climates or delayed until the soil is warm enough for satisfactory emergence in cool climates (Kigel et al., 2015).

This work was designed to test the relationship between seed water uptake and germination and seedling emergence when seed moisture is above $12 \% \leq$ and optimum soil temperature in bean seeds. This could be a fast discriminative feature in between high and lowquality seed lots regarding germination and seedling emergence potential.

\section{Material and Methods}

Nine different white-coated French bean (Phaseolus 


\section{Black Sea Journal of Agriculture}

vulgaris L. cvs Algan, Turna, Burçin, Seçil, Özlem, Albus, Suzan, Gentile, Gaudi) cultivars were obtained from different lots. Seeds were washed with distilled water and dried on paper towels at room temperature, and ventilated until they regained their original moisture content. Initial seed moisture content was determined by using the high-temperature oven method (ISTA, 2020). Seeds were kept at $100 \%$ relative humidity over a night (16 h) before germination and emergence tests. Seed weight was calculated with four replicates of 10 seeds and mean was taken as seed weight for the cultivar. Seeds with cracks on the seed coat were eliminated from the lots. Germination test was conducted on three replicates of 50 seeds in between wet towel papers for 8 days at $25^{\circ} \mathrm{C}$ (ISTA, 2020) in the dark. Towel papers were placed in plastic bags and placed into the incubator. Total ( $2 \mathrm{~mm}$ radicle emergence) and normal (well-developed seedlings) germination percentages were evaluated after 8 days. Seed water uptake was determined in three replicates of 10 seeds in each lot seeds were weighed and placed on top of $90 \mathrm{~mm}$ diameter Petri dishes (wetted, $5 \mathrm{ml}$ of distilled water of Whatman papers) at room temperature. Then seeds were weighed after 2 and 6 hours and water uptake were determined as \%, compared to the initial weight.

The mean germination time (MGT) was calculated by using the formula (equation 1);

$$
M G T=\frac{\sum n \cdot t}{\sum n}
$$

where, $\mathrm{n}=$ number of seeds newly emerged $(2 \mathrm{~mm}$ radicle emerged) at time $\mathrm{t}, \mathrm{t}=$ days from sowing, and $\sum \mathrm{n}=$ final germination.

Seeds (three replicates of 50 seeds/lot) were sown $4 \mathrm{~cm}$ deep in a mixture of garden soil/peat moss (Plantaflour, Germany), in seedling trays $(32 \times 16 \times 6 \mathrm{~cm})$ in an unheated glasshouse. Daily minimum and maximum temperatures varied between $9^{\circ} \mathrm{C}$ and $29^{\circ} \mathrm{C}$ respectively. The number of emerged seedlings (unfolding cotyledons on the surface) was calculated after 16 days.

Electrical conductivity measurements were done on two replicates of 10 weighed $(0.001 \mathrm{~g})$ seeds of each lot in 50 $\mathrm{ml}$ distilled water after 4 hours of soaking at $20^{\circ} \mathrm{C}$ in dark. The results were expressed as $\mu \mathrm{Scm}^{-1} \mathrm{~g}^{-1}$.

Significant differences between experimental groups were assessed with one-way ANOVA, using SPSS statistical program. Determination of coefficient $\left(R^{2}\right)$ values and regression equations were determined to assess the prediction potential of seed water uptake.

\section{Results and Discussion}

Total germination percentages were ranged from 97 and $100 \%$, normal germination was between 43 and $99 \%$. Differences in normal germination percentages were significant $(\mathrm{P}<0.05)$ but this was not the case in total germination. All seed lots were germinated fast, MGT was 0.95 and 1.82 days. The cultivar lot 4 had the lowest normal germination even though it had $100 \%$ total germination. The highest total and normal germination were obtained from lot 6 which was the smallest cultivar with seed weight $0.9 \mathrm{~g} / 10$ seeds. Seeds affect the germination percentage at the time of germination; legumes affect production grain (Adebisi et al., 2013). Usually, small seeds germinate faster because large seeds need more water absorption than small seeds and consequently more time to germinate. A similar result was found by Shahi et al. (2015) showed that the germination rate index of large size wheat seeds is lower than that of small and medium seeds. The seed weights of the other 9 cultivars varied between 2.3 and $4.8 \mathrm{~g} / 10$ seeds. Moisture content was ranged between 13.0 and $15.7 \%$ among the lots (Table 1). Seedling emergence percentages showed significant differences among the lots. Electrical conductivity values ranged between 48.5 and $144.1 \mu \mathrm{S} \mathrm{cm}^{-1} \mathrm{~g}^{-1}$ seed. Seed water uptake was the lowest in lot 6 as $20.43 \%, 32.47 \%$, the highest in lot 9 as $50.89 \%$ and 56.36, after 2 and 6 h of imbibition (Table 2). Seed water uptake after 2 and 6 hours was related significantly $(\mathrm{P}<0.05$ and $\mathrm{P}<0.01)$ to normal germination (Figure 1), mean germination time (Figure 2) seedling emergence (Figure 3) and electrical conductivity readings (Figure 4). Seed water uptake was also related to normal seedling emergence percentages and electrical conductivity readings at $\mathrm{P}<0.05-\mathrm{P}<0.01$ level (Figures 2 and 4).

Table 1. Total germination (2 mm radicle emergence, TG, \%), normal germination (NG, \%), mean germination time (MGT, h), 10 seed weight (SW, g) and seed moisture content (MC, \%) of white French bean seed cultivars

\begin{tabular}{lccccccccc}
\hline \multicolumn{1}{c}{ Seed lots } \\
\hline Criterion & 1 & 2 & 3 & 4 & 5 & 6 & 7 & 8 & 9 \\
\hline TG (\%) & 100 & 97 & 100 & 100 & 100 & 100 & 100 & 100 & 100 \\
NG (\%) & 63 & 67 & 65 & 61 & 61 & 43 & 79 & 60 & 99 \\
MGT (h) & 1.66 & 1.16 & 1.24 & 1.37 & 1.31 & 1.82 & 1.42 & 1.40 & 0.95 \\
SW (g) & 4.2 & 2.3 & 3.7 & 4.4 & 4.8 & 4.7 & 3.5 & 3.2 & 0.9 \\
MC (\%) & 14.6 & 14.6 & 15.3 & 13.5 & 14.7 & 15.7 & 13.7 & 13.9 & 13.0 \\
\hline
\end{tabular}




\section{Black Sea Journal of Agriculture}

Table 2. Seedling emergence (\%), mean emergence time (d), electrical conductivity at 6th hours (EC), and seed water uptake (SWU) at 2 and 6th hours in white French bean seed lots

\begin{tabular}{|c|c|c|c|c|c|c|c|c|}
\hline \multirow{2}{*}{\multicolumn{3}{|c|}{ Seed lots SE (\%) }} & \multicolumn{2}{|c|}{$\mathrm{EC}\left(\mu \mathrm{Scm}^{-1} \mathrm{~g}^{-1}\right)$} & \multicolumn{4}{|c|}{ SWU (\%) } \\
\hline & & & & & \multicolumn{2}{|c|}{$2 \mathrm{~h}$} & \multicolumn{2}{|c|}{$6 \mathrm{~h}$} \\
\hline 1 & 63 & c & 77.6 & $\mathrm{f}$ & 24.51 & $\mathrm{~d}$ & 34.67 & ef \\
\hline 2 & 81 & $\mathrm{ab}$ & 97.1 & g & 25.55 & $\mathrm{~d}$ & 47.25 & bc \\
\hline 3 & 63 & $\mathrm{c}$ & 67.2 & $\mathrm{e}$ & 23.23 & $\mathrm{~d}$ & 35.99 & ef \\
\hline 4 & 77 & abc & 65.4 & d & 30.64 & c & 43.23 & $\mathrm{~cd}$ \\
\hline 5 & 45 & $\mathrm{~d}$ & 48.5 & a & 22.67 & $\mathrm{~d}$ & 33.06 & $\mathrm{f}$ \\
\hline 6 & 79 & abc & 59.8 & $b$ & 20.43 & $\mathrm{~d}$ & 32.47 & $\mathrm{f}$ \\
\hline 7 & 80 & abc & 99.6 & $\mathrm{~h}$ & 43.82 & $\mathrm{~b}$ & 50.07 & $\mathrm{~b}$ \\
\hline 8 & 68 & $\mathrm{bc}$ & 61.4 & c & 24.97 & $\mathrm{~d}$ & 39.28 & $\mathrm{de}$ \\
\hline 9 & 88.0 & $\mathrm{a}$ & 144.1 & 1 & 50.89 & $\mathrm{a}$ & 56.36 & $\mathrm{a}$ \\
\hline
\end{tabular}

The same letters in a column do not differ significantly at $\mathrm{P}<0.05$. Letters are started to be given from the shortest value at EC.

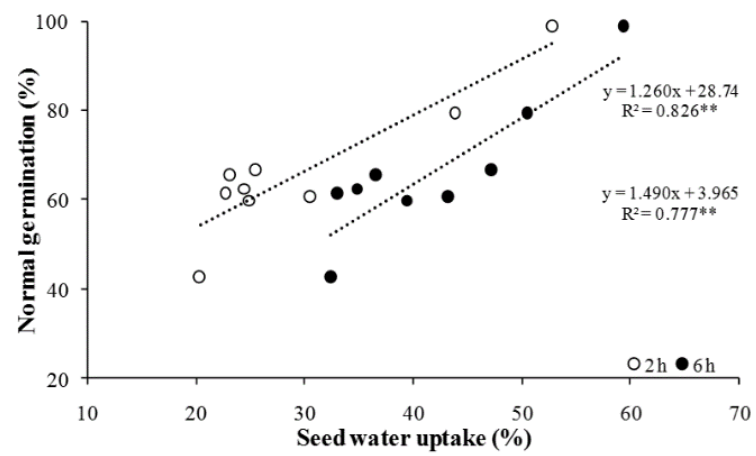

Figure 1. The relationship between normal germination $(\%)$ and seed water uptake (\%) at in white seed lots of French bean cultivars. \%, $2 \mathrm{~h}(\mathrm{O})$ and $6 \mathrm{~h}(\bullet)$ and electrical conductivity (EC, $\left.\mu \mathrm{Scm}^{-1} \mathrm{~g}^{-1}\right)$.

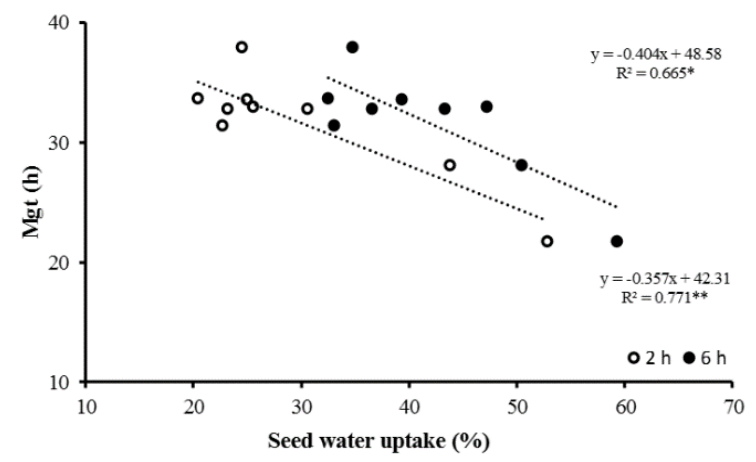

Figure 2. The relationship between mean germination time (h) and seed water uptake (\%) at in white seed lots of French bean cultivars. \%, $2 \mathrm{~h}(\mathrm{O})$ and $6 \mathrm{~h}(\bullet)$ and electrical conductivity (EC, $\mu \mathrm{Scm}^{-1} \mathrm{~g}^{-1}$ ).

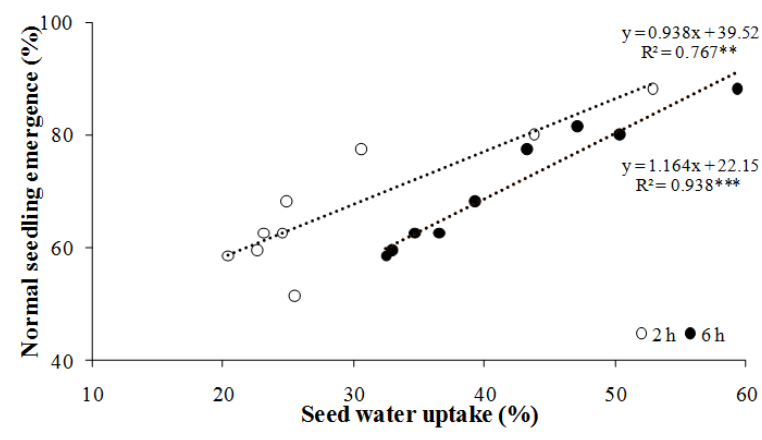

Figure 3. The relationship between normal seedling emergence (\%) and seed water uptake (\%) at in white seed lots of French bean cultivars. \%, $2 \mathrm{~h} \mathrm{(O)}$ and $6 \mathrm{~h}(\bullet)$ and electrical conductivity (EC, $\mu \mathrm{Scm}^{-1} \mathrm{~g}^{-1}$ ).

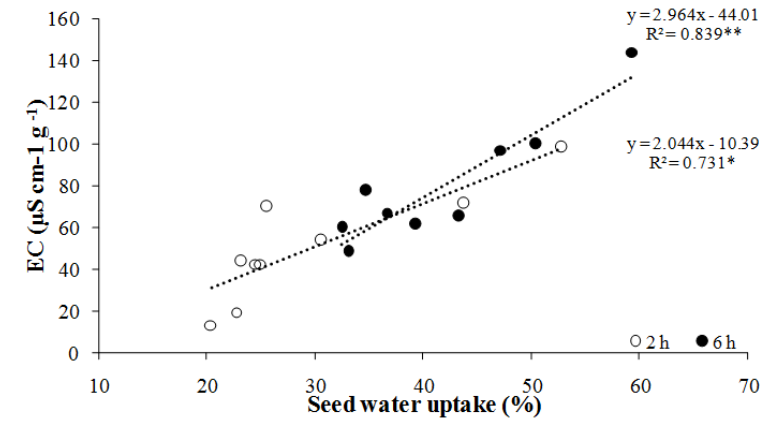

Figure 4. The relationship between seed water uptake values in white lots of French bean cultivars. \%, 2h (O) and $6 \mathrm{~h}(\bullet)$ and electrical conductivity (EC, $\mu \mathrm{Scm}^{-1} \mathrm{~g}^{-1}$ ).

Various seed characteristics were related to water uptake Balesevic-Tubic et al. (2005) found that the ageing process affected sunflower seeds' imbibition rate. Imbibition rate was faster in seeds which stored in ambient conditions than those at $4^{\circ} \mathrm{C}$. They concluded that the sorptive characteristics of seed may be influenced by changes in cellular level by ageing. In our work, the seed lots with the lowest normal germination did not imbibe faster than highly germinated ones like lots 3 and 5. This obviously showed that ageing itself in this work was not a factor in the imbibition rate. In sorghum seeds, less mature seeds (pale colour) had lower density and were imbibed faster than mature (dark-coloured) seeds. The faster imbibition was accompanied by high electrolyte leakage which was related to low germination in the final stage. They concluded that the physical proportion of the seed pericarp is influential in governing water uptake and leakage (Shephard and Naylor, 1996) in sorghum. In our work, the seed lots were commercially available ones so the difference in maturity among the lots were not known.

Faster imbibition in dwarf white French bean cultivars resulted in higher electrolyte leakage and lower normal seedling emergence (Powell et al., 1986). They concluded that adherence loss of seed coat in white-coated cultivars, induces imbibition injury, unlike the coloured ones. In our work, we used only white cultivars. We were not able to compare white and coloured cultivars. While our results are controversial with these conclusions. 
Basically, faster seed water uptake did not associate with lower germination, emergence and germination time (Figures 1 and 2). The reason for that may be the seed growing/testing conditions. We raised seed moisture above $13 \%$ and sow seeds to relatively high temperatures (Demir, 1996), while Powell et al. (1986) tested emergence initially at $4{ }^{\circ} \mathrm{C}(6 \mathrm{~h})$ then $20{ }^{\circ} \mathrm{C}$. Moreover, the seed moisture content in their work was 8$9 \%$, lower than our samples. Moreover, in our work seeds were not subjected to chilling during imbibition. It was proposed that low temperature during early imbibition increased the occurrence of damage in cell walls in peas (Powell and Matthews, 1978).

Bean cultivation in a Mediterranean climate, in some regions, overlaps summer months i.e., mid of June. In the southern part of Turkey, beans are sown after barley and wheat were harvested at the beginning of summer. So, the soil temperature is reasonably high and dry. In such cases, fast water uptake by seeds is positively related to normal germination, seedling emergence and electrolytic leakage. That appears to be that imbibitional injury may be strictly related to cold/wet sowing environments (Powell and Mathews, 1978; Powell, 2006). This may be one reason why our results do not agree with earlier reports in white French beans. Kolasinska et al. (2000) found that soil temperature at sowing appeared to be the most important environmental factor influencing field emergence and a factor that can distinguish the potential for a seed lot to emerge from the field. However, further investigations are necessary to confirm that by using a larger number of seed lots.

Fast and effective germination prediction has value in seed testing. Our work indicates that seed water uptake of 2 or $6 \mathrm{~h}$ can give a pre-testing indication of normal germination percentages. Faster imbibition resulted in high normal germination (Figure 1). Leftover seeds may also be selected according to their water uptake regarding normal germination potential. Higher seed water uptake was associated with faster germination i.e., lower mean germination time.

As a result, fast water uptake in white French beans is an indication of higher normal germination and better seedling emergence potential in the field. However, we tested this at optimum temperatures. Results may be different at lower sowing conditions which require further investigations.

\section{Author Contributions}

SE initiated the research idea, developed, organized, analyzed, collected and interpreted the data. GO analyzed the data, produced the figures. ID supervised the research, structured the paper and edited the manuscript. All authors reviewed and approved the manuscript.

\section{Conflict of Interest}

The author declared that there is no conflict of interest.

\section{References}

Abdullah WD, Powell AA, Matthews S. 1991. Association of differences in seed vigour in long bean (Vigna sesquipedalis L.) with testa colour and imbibition damage. J Agri Sci, 116: 259-264.

Adebisi MA, Kehinde TO, Salau AW, Okesola LA, Porbeni JBO, Esuruoso AO, Oyekale KO. 2013. Influence of different seed size fractions on seed germination, seedling emergence and seed yield characters in tropical soybean (Glycine max L. Merrill). Int J Agri Res, 8(1): 26-33.

Balesevic-Tubic S, Tatic M, Miladinovic J. 2005. Influence of natural ageing on the dynamics of water absorption by sunflower seed. Seed Sci Tech, 33: 255-258.

Demir I. 1996. The effects of testa colour, temperature and seed moisture content of occurrence of imbibition damage in beans. Turkish J Agri Forest, 20: 295-298.

ISTA. 2020. International rules for seed testing. International Seed Testing Association. Bassersdorf, Switzerland.

Kigel J, Rosental L, Fait A. 2015. Seed physiology and germination of grain legumes, in Grain Legumes. Series: Handbook of Plant Breeding, ed A. M. De Ron. Springer, New York, NY, US, pp: 363.

Kolasinska K, Szyrmer J, Dul S. 2000. Relationship between laboratory seed quality tests and field emergence of common bean seed. Crop Sci, 40: 470-475.

Legesse N, Powell AA. 1992. Comparison of water uptake and imbibition damage in eleven cowpea cultivars. Seed Sci Tech, 20: 173-180.

Matthews S, Powell AA. 2011. Electrical conductivity vigour test: Physiological basis and use. Seed Testing Int, 131: 32-35.

Nonogaki H, Bassel GW, Bewley JD. 2010. Germination-still a mystery. Plant Sci, 176: 574-581.

Powell AA, Matthews S. 1978. The damaging effect of water on dry pea embryos during imbibition. J Exper Botany, 29: 12151229.

Powell AA, Oliveira MA, Matthews S. 1986. The role of imbibition damage in determining the vigour of white and coloured seed lots of dwarf French Beans (Phaseolus vulgaris L.). J Exper Botany, 37: 716-722.

Powell AA. 2006. Seed vigour assessment. In Handbook of Seed Science (ed. A.S. Basra) Haworth Press, New York, US, pp: 648.

Shahi C, Vibhuti, Bargali K, Bargali SS. 2015. How seed size and water stress affect the seed germination and seedling growth in wheat varieties? Current Agri Res J, 3: 60-68.

Shephard HL, Naylor REL. 1996. Effect of seed coat on water uptake and electrolyte leakage of sorghum (Sorghum bicolor (L.) Moench seeds. Annals of App Biol, 129: 125-136.

Zhang XK, Yang GT, Chen L, Yin JM, Tang ZL, Li JN. 2006. Physiological differences between yellow-seeded and blackseeded rapeseed (Brassica napus L.) with different testa characteristics during artificial ageing. Seed Sci Tech, 34: 373-381 